\title{
Palynological study of some Iranian Amaranthus taxa
}

\author{
Seyed Mehdi Talebi*, Mitra Noori, Zeinab Nasiri \\ Department of Biology, Faculty of Science, Arak University, Arak, Iran \\ *Corresponding author, E-mail: seyedmehdi_talebi@yahoo.com
}

\begin{abstract}
There has been much discussion about infrageneric taxonomy of the genus Amaranthus. In the present study, in order to solve taxonomical problems and to aid identification of Iranian Amaranthus taxa, the palynological characteristics of seven taxa from two subgenera (Amaranthus and Albersia) were examined. Pollen grains were investigated with light microscopy and scanning electron microscopy using the prolonged acetolysis procedure. Twelve quantitative and qualitative characteristics were studied. Results showed that all of the studied taxa had poly pantoporate pollen and surface sculpturing was seen as scabrate, while its aggregation differed between samples. Statistical analysis showed that some quantitative morphological features were more valuable in identification of the studied taxa. The studied taxa were separated from each other using multivariate analysis. Our data together with the results of previous investigations confirmed that the present infraspecific classification of A. blitum requires change. It is advisable to return to the previous taxonomical status of the genus.
\end{abstract}

Key words: Amaranthus, pollen characteristics, taxonomy.

Abbreviations: PCA, principal coordinate analysis; PCO, principal coordinate ordination; UPMGA, unweighted paired group using average.

\section{Introduction}

Approximately 60 Amaranthus L. species are native to the Americas, and an additional 25 species are present in the temperate and tropical regions of Africa, Asia, Australia, and Europe (Sauer 1967). Often collectively called "pigweeds," at least 10 Amaranthus species are considered troublesome weeds in the North America (Horak et al. 1994; Wax 1995). The cultivated taxa of the genus are utilized as food grains, leafy vegetables, and forage crops in different geographic areas of America, Asia and Europe (Stallknecht, SchulzSchaeffer 1993).

The genus Amaranthus naturally grows in Iran and is found in several regions of the country (Azadi 2013). There has been much discussion about its species number: Mobayen (1979) reported six species, Ghahreman (19802002) more than seven species and Rechinger (1998) 11 species in Iran. These differences were due to hybridization and domestication of some of the species.

Identification of species of Amaranthus is necessary for an effective weed management (Mayo et al. 1998). Because of the large genetic and morphological diversity within the genus Amaranthus, species identification is difficult. The presence of flowers is required to identify most species. In addition, interspecific hybridization between Amaranthus species causes further difficulties in identification, as these hybrids can exhibit characteristics of both parents (Horak et al. 1994).

In modern systematics pollen morphology has been extremely useful in clarifying systematic relationships within plant taxa. Moreover, palynology of the species and subspecies can have taxonomic value as supporting evidence to morphological and phylogenetic traits. Also, studies on pollen grains morphology is considered as the basic necessity for palynology due to its fundamental value in the recognition and identification of grains found in various conditions (Arora, Modi 2008). Iwanami et al. (1988) considered that the morphology of the pollen grain is generally a conserved characteristic, which is an excellent means for identification of most species.

Previous studies (Eliasson 1988; Costea 1998a; Costea 1998b; Costea et al. 2004) have confirmed that in Amaranthus taxa, flowers lack nectar glands and pollen grains are small (diameter 18 to $28 \mu \mathrm{m}$ ), usually with 30 to 45 pores uniformly distributed on their surface. In addition, they are tectate with granules and spinules. The relationship between monoecious and dioecious Amaranthus as well as different ploidy level and interspecific hybrids can be determined using pollen grain features. Pollen grains of dioecious species have a larger number of apertures on the visible surface. The arrangement of pores creates high air turbulence, which minimizes the friction between the pollen grain and the air, therefore increasing the distance at which the pollen grain can be dispersed (Franssen et al. 2001). Roulston and Buchmann (2000) believed that Amaranthus pollens contain starch (up to $7.5 \%$ ), which protects them against desiccation.

Studies showed that the genus Amaranthus is a 
problematic genus from a taxonomic point of view (Brennan 1961; Robertson 1981). As a result, infrageneric classification of Amaranthus species in sections or subgenera is always controversial or in correction. Yet, many classification schemes have been proposed for the genus and its species have been classified in several subgenera (Sauer 1955; Mosyakin, Robertson 1996) or subgenera with sections (Carretero 1979; Hugin 1987; Klopper, Robel 1989). In addition, the distinctions between some sections are also not clear.

In order to solve the above mentioned taxonomical problems and to facilitate better identification of Iranian Amaranthus taxa, in the present study, palynological characteristics of seven taxa from two subgenera [Amaranthus and Albersia (Kunth) Gren. \& Godr.] were investigated in Iran.

\section{Materials and methods}

\section{Plant collection, determination and sample preparation}

Plant samples of seven taxa from two subgenera were collected: Amaranthus, including A. coadatus L. and A. retroflexus L.; and Albersia (Kunth) Gren. \& Godr., including A. albus L., A. blitoides S. Wats., A. blitum L. subsp. blitum and $A$. blitum subsp. emarginatus The samples were collected from natural populations in different regions of Tehran Province, Iran during spring and summer of 2013. In each locality three to four individuals were collected randomly. Details of localities are given in Table 1. Flowers of all collected plant species were fixed in Carnoy's solution (a fixative composed of glacial acetic acid and ethanol, 1:3).
Table 1. Localities of samples of the studied taxa of the genus Amaranthus

\begin{tabular}{|c|c|c|}
\hline Taxon & Locality & Altitude (m) \\
\hline A. albus & $\begin{array}{l}\text { Tehran province, } \\
\text { Firuozkooh. }\end{array}$ & 1930 \\
\hline A. blitoides & $\begin{array}{l}\text { Tehran province, Shahr-e } \\
\text { Rey }\end{array}$ & 1062 \\
\hline $\begin{array}{l}\text { A. blitum subsp. } \\
\text { blitum }\end{array}$ & $\begin{array}{l}\text { Tehran province, Robat } \\
\text { Karim }\end{array}$ & 1024 \\
\hline $\begin{array}{l}\text { A. blitum subsp. } \\
\text { emarginatus }\end{array}$ & $\begin{array}{l}\text { Tehran province, Qaleh } \\
\text { Morqi }\end{array}$ & 1062 \\
\hline A. coadatus & $\begin{array}{l}\text { Tehran province, Shariati } \\
\text { Park }\end{array}$ & 1062 \\
\hline A. retroflexus & Tehran province, Jajroud & 1133 \\
\hline A. tricolor & $\begin{array}{l}\text { Tehran province, } \\
\text { Firuozkooh }\end{array}$ & 1900 \\
\hline
\end{tabular}

\section{Light microscopy}

Pollen grains were obtained from flowers of inflorescences. For each taxon, three specimens were used, and from each specimen at least three anthers were examined. Pollen grains were prepared for light microscopy and scanning electron microscopy using the prolonged acetolysis procedure (Erdtman 1952). For light microscopy, the pollen grains were mounted in glycerine jelly and sealed with paraffin. Some palynological characteristics, such as equatorial diameter $(E)$, polar axis length $(P), P / E, \log P / E$, exine ornamentation and pore dimensions, were described for each sample (Table 2).

Table 2. Some important palynological characteristics of the studied Amaranthus taxa (all measured values are in $\mu \mathrm{m}$ )

\begin{tabular}{|c|c|c|c|c|c|c|c|c|}
\hline Taxon & $\begin{array}{c}\text { Polar length } \\
\text { (P) }\end{array}$ & $\begin{array}{l}\text { Equatorial } \\
\text { length }(E)\end{array}$ & $\mathrm{P} / \mathrm{E}$ & $\begin{array}{c}\text { Pore } \\
\text { diameter }\end{array}$ & $\begin{array}{l}\text { Polar length/ } \\
\text { pore diameter } \\
\text { ratio }\end{array}$ & $\begin{array}{c}\text { Equatorial } \\
\text { length/pore } \\
\text { diameter } \\
\text { ratio }\end{array}$ & Polar shape & $\begin{array}{c}\text { Equatorial } \\
\text { shape }\end{array}$ \\
\hline A. albus & $24.5 \pm 1.3$ & $26.0 \pm 1.5$ & 0.94 & $1.14 \pm 0.75$ & 21.5 & 22.8 & circular & $\begin{array}{l}\text { elliptic- } \\
\text { truncate }\end{array}$ \\
\hline A. blitoides & $24.4 \pm 2.0$ & $25.1 \pm 1.7$ & 0.97 & $1.63 \pm 0.86$ & 15.0 & 15.4 & circular & $\begin{array}{l}\text { elliptic- } \\
\text { truncate }\end{array}$ \\
\hline $\begin{array}{l}\text { A. blitum } \\
\text { subsp. blitum }\end{array}$ & $20.5 \pm 0.6$ & $21.0 \pm 0.5$ & 0.97 & $2.45 \pm 1.15$ & 8.4 & 8.6 & circular & $\begin{array}{l}\text { elliptic- } \\
\text { truncate }\end{array}$ \\
\hline $\begin{array}{l}\text { A. blitum } \\
\text { subsp. } \\
\text { emarginatus }\end{array}$ & $23.9 \pm 1.0$ & $25.1 \pm 0.9$ & 1.05 & $0.98 \pm 1.23$ & 24.4 & 25.6 & circular & $\begin{array}{l}\text { elliptic- } \\
\text { truncate }\end{array}$ \\
\hline A. coadatus & $24.5 \pm 1.0$ & $25.3 \pm 0.8$ & 0.95 & $1.31 \pm 0.98$ & 18.7 & 19.3 & circular & $\begin{array}{l}\text { elliptic- } \\
\text { truncate }\end{array}$ \\
\hline A. retroflexus & $24.0 \pm 1.8$ & $25.0 \pm 1.1$ & 0.96 & $0.81 \pm 0.83$ & 29.6 & 30.9 & circular & $\begin{array}{l}\text { elliptic- } \\
\text { truncate }\end{array}$ \\
\hline A. tricolor & $25.4 \pm 0.8$ & $25.9 \pm 0.8$ & 0.98 & $1.47 \pm 0.73$ & 17.3 & 17.6 & circular & $\begin{array}{l}\text { elliptic- } \\
\text { acuminate }\end{array}$ \\
\hline
\end{tabular}



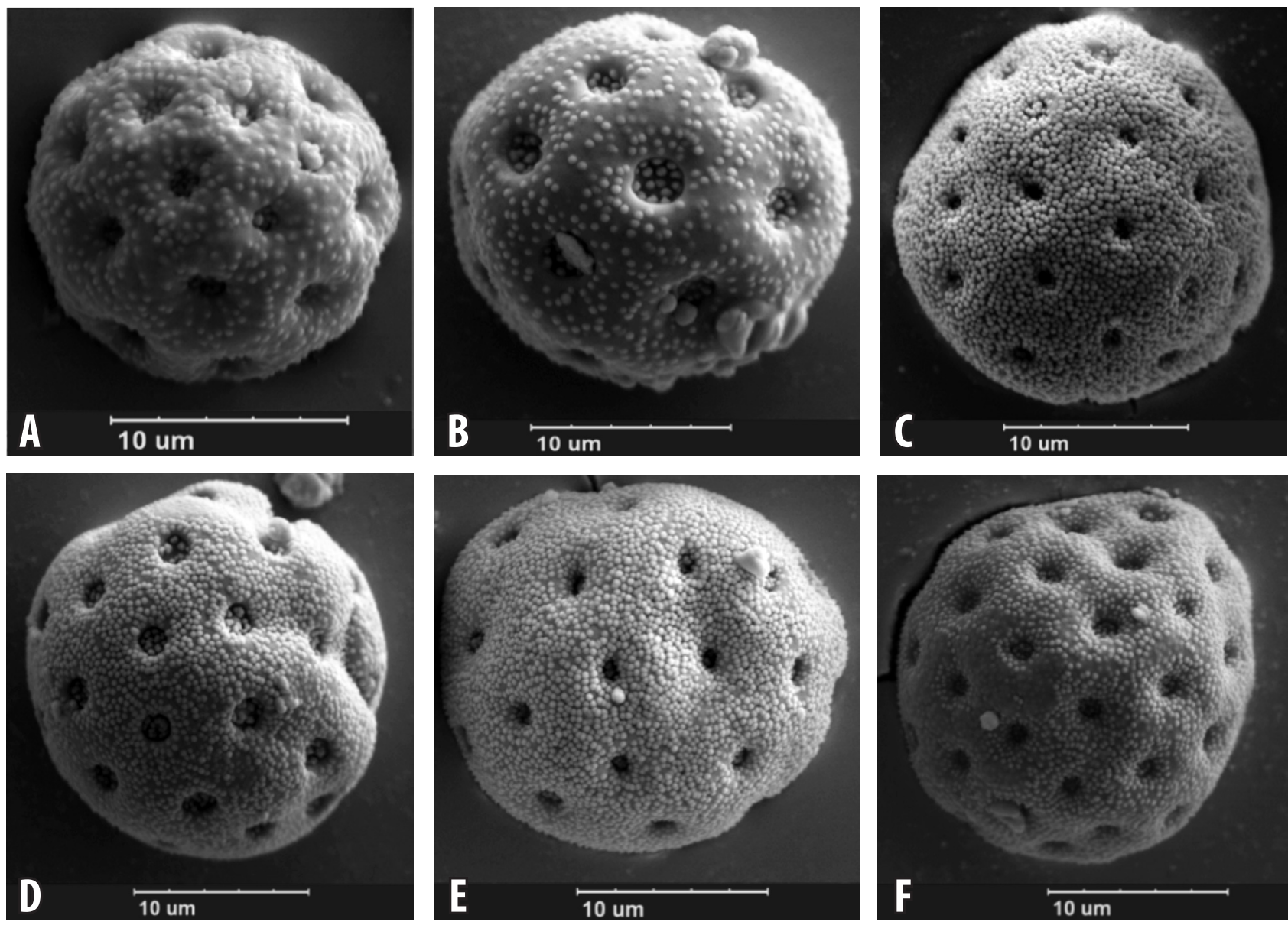

Fig. 1. Scanning electronic microscope images of pollen in studied Amaranthus taxa. A, A. blitum subsp. emarginatus; B, A. blitum subsp. blitum; C, A. coadatus; D, A. blitoides; E, A. retroflexus; F, A. tricolor.

\section{Statistical analysis}

For grouping the studied taxa, data were standardized (mean $=0$, variance $=1$ ) and used for the multivariate analyses with unweighted paired group average (UPGMA), principal coordinate ordination (PCO), and principal coordinate analysis (Podani 2000). MVSP (version 2) and SPSS Ver. 9 (1998) were used for the analysis.

\section{Results}

In this study palynological traits of seven Amaranthus taxa, including A. albus, A.blitoides, A.blitum subsp. blitum, A. blitum subsp. emarginatus, A. coadatus, A. retroflexus and A. tricolor were studied. Twelve quantitative and qualitative characteristics were investigated (Table 2). Results showed that all of the studied taxa had poly pentaporate pollen, with many pores distributed on the surface of pollen. Pollen polar shapes were stable in the studied taxa and were circular. In addition, equatorial views in the all of taxa were elliptic-truncate with the exception of A. tricolor that was elliptic-acuminate (Fig. 1).

In all examined taxa, surface sculpturing were seen as scabrate, while its aggregation differed between samples.
Dense aggregations were recorded in A. retroflexus, while sparse aggregation occurred in A.blitum subsp. blitum, A. albus and also A. blitum subsp. emarginatus (Fig. 2). Furthermore, quantitative traits varied between taxa. For example, polar axis length $(20.5 \mu \mathrm{m})$ as well as equatorial diameter $(21.0 \mu \mathrm{m})$ was shortest in A. blitum subsp. blitum, and largest polar $(25.4 \mu \mathrm{m})$ and equatorial $(26.0 \mu \mathrm{m})$ length in A. tricolor and A. albus. Pore diameter varied between the studied taxa. the largest pores were found in A. blitum subsp. blitum $(2.45 \mu \mathrm{m})$, and smallest in A. retroflexus $(0.81$ $\mu \mathrm{m})$.

Significant negative/positive correlation were found between the studied quantitative palynological traits. For example, a significant positive correlation $(r=0.97, P<0.01)$ was recorded between polar axis length with equatorial diameter. Equatorial diameter had a negative correlation $(r$ $=-0.80, P<0.05)$ with pore diameter.

Box and whisker plots showed that some quantitative morphological features were more valuable in identification of the studied taxa. For example, $P / E$ ratio was a distinct characteristic in identification of A. blitum subsp. emarginatus from the other taxa. Pore diameter, equatorial and also polar axis length were the main characteristics for 

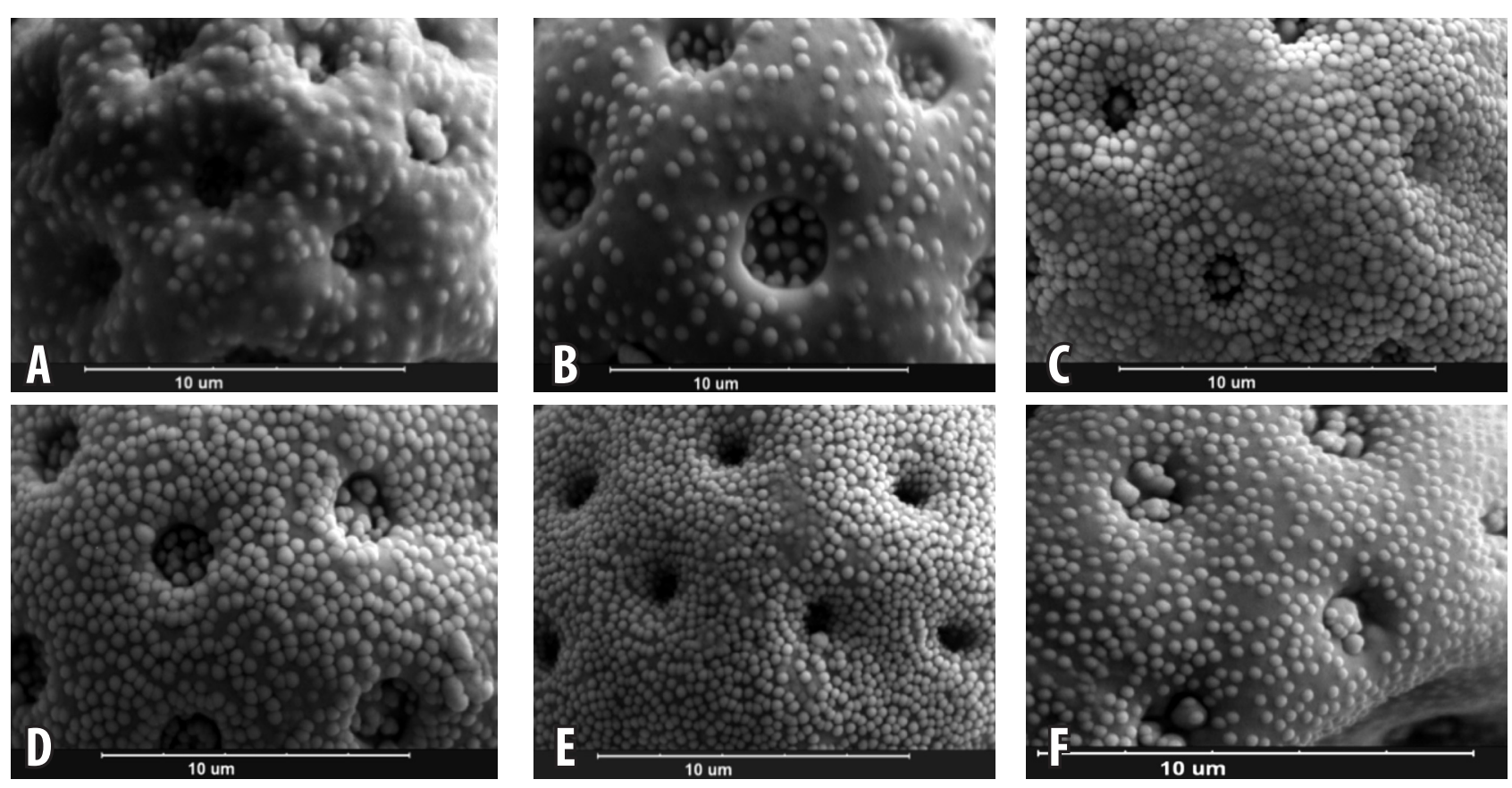

Fig. 2. Surface sculpturing shapes of pollen in the studied Amaranthus taxa. A, A. blitum subsp. emarginatus; B, A. blitum subsp. blitum; C, A. coadatus; D, A. blitoides; E, A. retroflexus; F, A. tricolor.

recognition of A. blitum subsp. blitum from the other taxa (Fig. 3). PCA analysis showed two factors which together explained $78 \%$ of total variance. The first factor $(54 \%$ of variance) had significant positive correlation with polar and equatorial axes length, and a negative significant correlation with pore diameters (for details see Tables 3 and 4). The first few PCA axes represent the majority of variation in the data set and thus represent significant differences among taxa (Fig. 5).

The studied taxa were separated from each other in a UPGMA tree (Fig. 4). Furthermore PCA and PCO plots (Fig. 5 and 6) showed similar results. In the UPGMA analysis two main clusters were seen. One contained $A$. blitum subsp. blitum and the other taxa were clustered in other branch, which had two sub-clusters: one of them
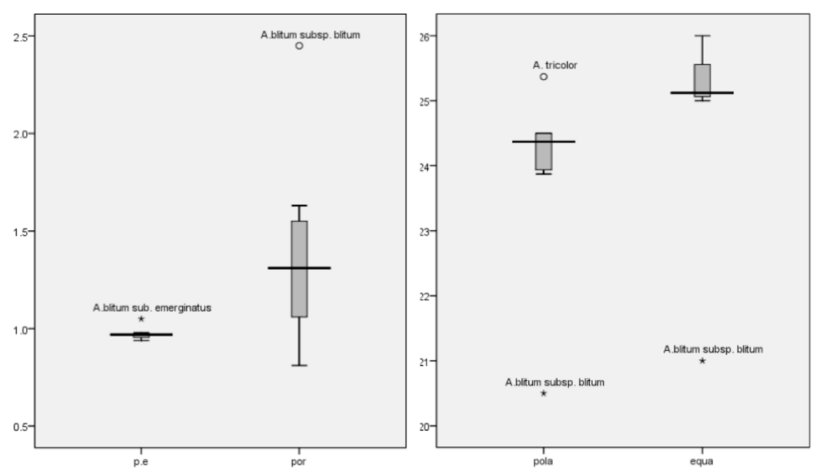

Fig. 3. Box and Whisker plots of palynological traits of the studied Amaranthus taxa. p.e, $P / E$ ratio; por, pore diameter; pola, polar axis length; equa. equatorial axis length included $A$. retroflexus and the other had two distinct groups. In small group A. albus and A. blitum subsp. emarginatus showed similarity and A. blitoides, A. coadatus and $A$. tricolor clustered closely in the larger group.

\section{Discussion}

There has been much discussion about infrageneric taxonomy of the genus Amaranthus (Carretero 1979; Hugin 1987; Klopper, Robel 1989), and in spite of the fact that the genus has been the subject of many taxonomic studies, it is still poorly understood and is widely considered to be a difficult genus. On the other hand, its infrageneric classification is still unresolved. For these reasons, in this study palynological features were used for identification of infraspecific and infrageneric taxa in the genus. Some studies (for example, Pandey, Misra 2009; Zhigila et al. 2014a) showed that pollen morphological characteristics play a major role in solving taxonomic problems. Palynological characteristics have been able to reposition several disputed genera and interpret problems related to the origin and evolution of many taxa (Nair 1980) and to derive a classification of angiosperms (Cronquist 1981). The obtained results showed that pollen sizes were small and also thin-walled in the studied taxa. Since these taxa are anemophilous, these conditions facilitate their pollination. Sosnoskie et al. (2009) reported that some pollen physical traits in the genus Amaranthus, such as density, specifically size as well as settling velocity, can influence flight of pollen and also pollination. This was also true for the other taxa in the genus Amaranthus. For example, Zhigila 
Table 3. Total variance explained for principal component axes analysis for pollen characteristics in the studied Amaranthus taxa

\begin{tabular}{|c|c|c|c|c|c|c|c|c|c|}
\hline \multirow{2}{*}{$\begin{array}{l}\text { Compo- } \\
\text { nent }\end{array}$} & \multicolumn{3}{|c|}{ Initial Eigen values } & \multicolumn{3}{|c|}{ Extracted sums of squared loadings } & \multicolumn{3}{|c|}{ Rotation sums of squared loadings } \\
\hline & Total & $\begin{array}{c}\% \text { of } \\
\text { variance }\end{array}$ & $\begin{array}{c}\text { Cumulative } \\
\%\end{array}$ & Total & $\begin{array}{c}\% \text { of } \\
\text { variance }\end{array}$ & $\begin{array}{c}\text { Cumulative } \\
\%\end{array}$ & Total & $\begin{array}{c}\% \text { of } \\
\text { variance }\end{array}$ & $\begin{array}{c}\text { Cumulative } \\
\%\end{array}$ \\
\hline 1 & 2.691 & 53.823 & 53.823 & 2.691 & 53.823 & 53.823 & 2.655 & 53.094 & 53.094 \\
\hline 2 & 1.223 & 24.459 & 78.282 & 1.223 & 24.459 & 78.282 & 1.259 & 25.188 & 78.282 \\
\hline 3 & 0.788 & 15.761 & 94.043 & & & & & & \\
\hline 4 & 0.248 & 4.964 & 99.007 & & & & & & \\
\hline 5 & 0.050 & 0.993 & 100.000 & & & & & & \\
\hline
\end{tabular}

Table 4. Correlation of pollen characteristics of the studied Amaranthus taxa with two components of PCA

\begin{tabular}{lcc} 
Characteristic & Component & \\
& $\mathbf{1}$ & $\mathbf{2}$ \\
\hline Pore diameter & -0.905 & \\
Equatorial diameter & 0.891 & \\
Polar axis length & 0.868 & \\
$P / E$ & 0.535 & -0.518 \\
$\log P / E$ & & 0.896
\end{tabular}

et al. (2014b) provided evidence that Amaranthus species are eurypalynous (multipalynous) and that the genus is anemophilous. The pollen grains are generally small, rounded, smooth, thin-walled and dry but vary among species within this genus.

Quantitative palynological features varied between the studied taxa and were useful in identification of taxa. For example, based on equatorial shape, A. tricolor can be distinguished from the other taxa. Degree of sculpturing aggregates was useful in identification of $A$. retroflexus from the other taxa. The analyses (PCA and Box and Whisker plots) confirmed that most of the quantitative traits were useful in classification of Amaranthus species and had taxonomic value. For example polar and equatorial axes lengths were useful features in separating A. blitum

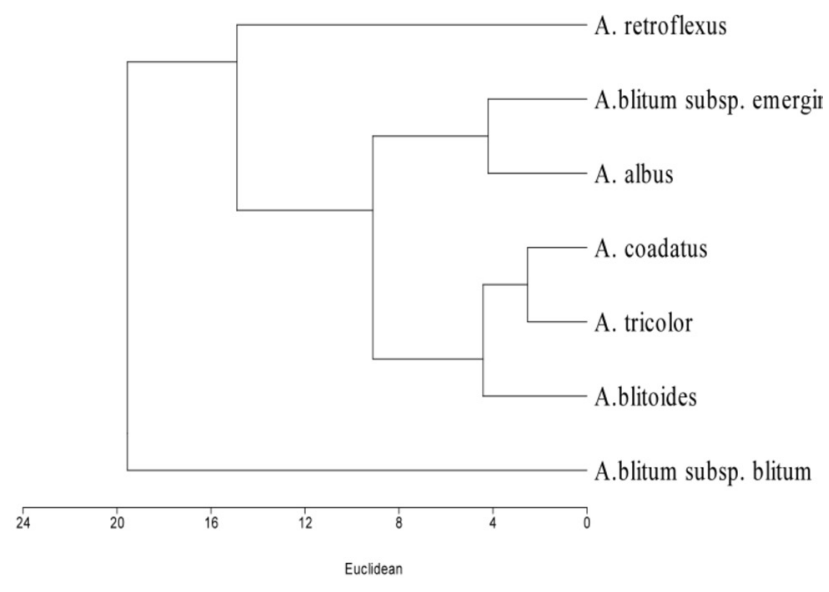

Fig. 4. UPGMA tree of the studied Amaranthus taxa based on palynological characteristics. subsp. blitum from other taxa. In addition, some pollen qualitative characteristics differed between taxa. For example, equatorial shape is a good feature in identification of $A$. tricolor from the rest. The marginal shape of pores also differed between the studied taxa. Various palynological investigations on different species of the genus Amaranthus confirmed importance of pollen traits for distinguishing taxa. For example, Zhigila et al. (2014b) studied palynological characteristics in five species (A. spinosus, A. viridis, A. hybridus, A. australis and A. tricolor) of this genus. Their results indicated that pollen characteristics may be used to delimit the species in Amaranthus.

Our results did not confirme species classifications in to the traditional subgenera of the members of subgenera (Amaranthus and Albersia) present in Iran, A. coadatus and $A$. retroflexus (two studied samples of subgenus Amaranthus) clustered separately and were placed far from the others. This cwas also true for members of the Albersia subgenus; and also, two subspecies of A. blitum (subsp. blitum and subsp. emarginatus) were separated far from each other. There was high palynological variation between these subspecies. Noori et al. (2015) compared flavonoids components of these taxa. In their study, the mentioned taxa separated from each other and results of phytochemical clustering did not confirm species classifications in subgenera. Particularly members of

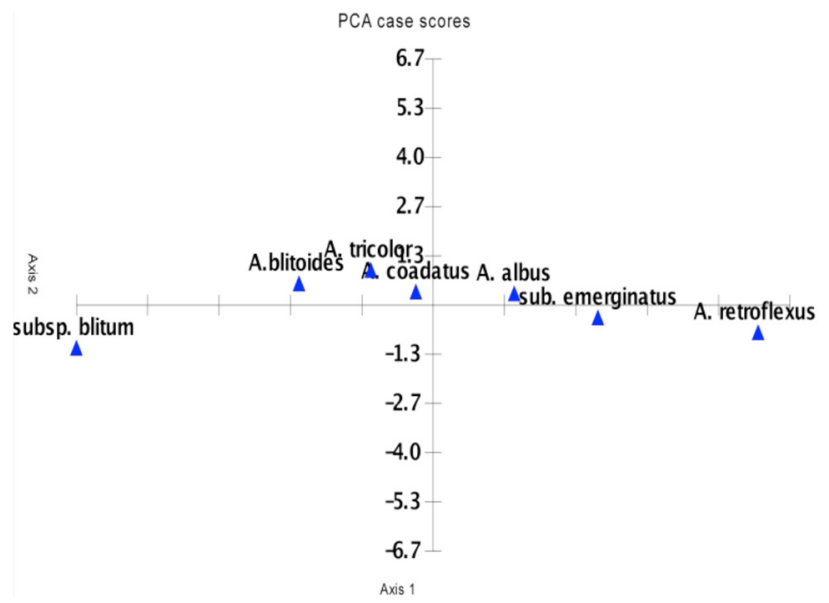

Fig. 5. PCA plot of the studied Amaranthus taxa based on pollen traits. 


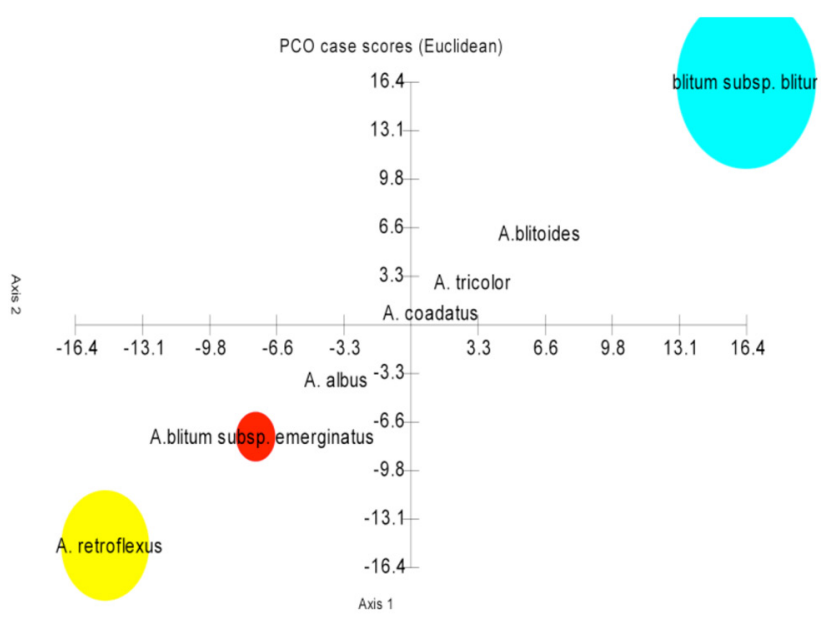

Fig. 6. PCO plot of the studied Amaranthus taxa based on pollen traits.

Albersia subgenus clustered separately from each other. In addition, two subspecies of A. blitum did not cluster closely.

Different patterns have been shown in infrageneric as well as infraspecific classifications of the genus: Sauer (1955) designated two subgenera: Acnida (L.) Allen ex K.R. Robertson, which includes dioecious species, and Amaranthus, which includes the monoecious species. Traditionally, the subgenus Amaranthus has been divided in two sections: Amaranthus and Blitopsis Dumert sensu lato (Carretero 1979, Hugin 1987). Carretero $(1985,1991)$ divided the section Blitopsis senso lato in two sections Blitopsis, which includes those species having indehiscent fruits $(\mathrm{x}=17)$; and Pyxidium, which includes those with dehiscent fruits $(\mathrm{x}=16)$. Another section, Puncticulatae, was proposed by Kowal (1954), but was not validated by later studies (Klopper, Robel 1989). Recently the subgeneric rank (Subgenus Albersia (Kunth) Gren. \& Godr.) has been given to the section Blitopsis senso lato. Mosyakin and Robertson (1996) designated three subgenera in the genus; subgenus Acnida (L.) Aellen ex K. R. Robertson, Amaranthus and Albersia (Kunth) Gren. \& Godr., on the basis of inflorescence and floral characteristics. Acnida comprises dioecious weeds. Amaranthus includes monoecious weeds and crop species, while Albersia contains many of the poorly characterized Amaranthus.

Wassom and Tranel (2005) believed that the classification of Mosyakin and Robertson (1996) was well substantiated by morphological features and also molecular data, but this pattern was challenged by the UPGMA tree of AFLP data. For example, all the dioecious taxa were grouped in the subgenus Acnida. This reveals the polyphyletic nature of Acnida and challenges the infrageneric classification of Mosyakin and Robertson.

Although, the infrageneric classification with three subgenera (Acnida, Amaranthus and Albersia) is based on classical characteristics, such as those of inflorescence and floral characteristics, the present results and also our previous investigations did not confirm this.

In the infraspecific classifications in this genus different synonyms are used for some species. For example, MoquinTandon (1849) described A. emerginatus for the first time. Later Carretero (1979) made new contribution and altered as A. blitum subsp. emarginatus. In addition in some references (such as Ghahreman 1980-2002), it was described as a variety of A. blitum. Similarly A. blitum subsp. blitum has been named $A$. lividus. Our data with the results of previous investigations confirmed that the present infraspecific classification of A. blitum must change. Perhaps it is advisable to return to the previous taxonomical status of the genus.

\section{References}

Arora A., Modi A. 2008. An acetolysis technique for pollen slide preparation. Indian J. Aerobiol. 21: 90-91.

Azadi R. 2013. Flora of Iran (Amaranthaceae). Research Institute of Forests and Rangelands, Tehran.

Brenan J.P.M. 1961. Amaranthus in Britain. Watsonia 4: 261-280.

Carretero J.L. 1979. El género Amaranthus en España. Collect. Bot. 11: 105-145.

Carretero M. 1985. Aprendizaje y desarrollo cognitivo. Un ejemplo del tratado del inútil combate. En: Mayor J. (ed.) Actividad humana y procesos cognitivos. Madrid, Alhambra.

Costea M. 1998a. Amaranthus L. subgenus Albersia (Kunth) Gren. \& Godr. in Romania. Rev. Roum. Biol. 43: 95-112.

Costea M. 1998b. Monograph of the Genus Amaranthus L. in Romania. University of Bucharest, College of Biology, Bucharest.

Cronquist A. 1981. An Integrated System of Classification of Angiosperms. Columbia University Press, New York.

Eliasson U. 1988. Floral morphology and taxonomic relation among genera of Amaranthaceae in the new world and the Hawaii islands. Bot. J. Linn. Soc. 96: 235-283.

Erdtman G. 1952. An Introduction to Palynology 1. Pollen Morphology and Plant Taxonomy, Angiosperms. Almquist Wiksell, Stockholm, Sweden.

Franssen A. S., Skinner D. Z., Al-Khatib K., Horak M. J. 2001. Pollen morphological differences in Amaranthus species and interspecific hybrids. Weed Sci. 49: 732-737.

Ghahreman A. 1980-2002. Color flora of Iran. Volumes 1-24. Research Institute of Forest and Rangelands, Tehran, Iran.

Horak M.J., Peterson D.E., Chessman D.J., Wax L.M. 1994. Pigweed identification: A Pictorial Guide to the Common Pigweeds of the Great Plains. Manhattan, University Cooperative Extension Service publication.

Hugin G. 1987. Einige Bemerkungen zu wenig bekannten Amaranthus-Sippen (Amaranthaceae) Mitteleuropas. Willdenowia 16: 453-478.

Iwanami Y., Sasakuma T., Yamada Y. 1988. Pollen morphology of flowering plants. In: Pollen Illustrations and Scanning Electromicrographs. Kodansha Press, Tokyo, pp. 10-122.

Klopper K., Robel J. 1989. Beitrage zur systematic morphologie und anatomie der gattung Amaranthus L. I karpomorphologie und anatomie ausgewahlter vertreter. Gleditschia 17: 3-21.

Mayo C.M., Horak M.J., Peterson D.E., Boyer J.E. 1998. Differential control of four Amaranthus species by six post emergence herbicides in soybeans (Glycine max). Weed Technol. 9: 
141-147.

Mobayen S. 1979. Flora of Iran. Vol. 2. Tehran University Press, Tehran.

Moquin-Tandon C.H.B.A. 1849. Amaranthaceae. In: de Candolle A. (ed.) Prodromus Systematis Naturalis Regni Vegetabilis. Paris, pp. 231-424.

Mosyakin S.L., Robertson K.R. 1996. New infrageneric taxa and combinations in Amaranthus (Amaranthaceae). Ann. Bot. Fenn. 33: 275-281.

Nair P.K.K. 1980. Pollen Morphology of Angiosperms. Vikas Publications, New Delhi.

Noori M., Talebi M., Nasiri Z. 2015. Seven Amaranthus L. (Amaranthaceae) taxa flavonoid compounds from Tehran Province, Iran. Int. J. Modern Bot. 5: 9-17.

Pandey S.N., Misra S.P. 2009. Taxonomy of Angiosperms. Parwana Bhawa, Darya Ganj, New Delhi, India.

Podani J. 2000. Introduction to the Exploration of Multivariate Biological Data. Backhuys Publishers, Leiden.

Rechinger K.H. 1998. Flora Iranica. Akademische Druck-und Verlag Sanstalt Graz, Austria.

Robertson K.R. 1981. The genera of Amaranthaceae in the South eastern United States. J. Arnold Arbor. 62: 267-313.

Roulston T.H., Buchmann S.L. 2000. A phylogenetic reconsideration of the pollen starch-pollination correlation. Evol. Ecol. Res. 2: 627-643.

Sauer J.D. 1967. The grain amaranths and their relatives: a revised taxonomic and geographic survey. Ann. Missouri Bot. Gard. 54: 101-113.

Sauer J.D.1955. Revision of the dioecious Amaranthus. Madrono 13: 5-46.
Sosnoskie L.M., Webster T.M., Dales D., Rains G.C., Grey T.L., Culpepper A.S. 2009. Pollen grain size, density, and settling velocity for palmer amaranth (Amaranthus palmeri). Weed Sci. 57: 404-409.

Stallknecht G.E., Schulz-Schaeffer J.R. 1993. Amaranth rediscovered. In: Janick J., Simon J.E. (eds.) New Crops. John Wiley and Sons, New York.

Wassom J.J., Tranel P.J. 2005. Amplified fragment length polymorphism-based genetic relationship among weedy Amaranthus species. J. Hered. 96: 410-416.

Wax L.M. 1995. Pigweeds of the Midwest - distribution, importance and management. Proc. Int. Crop Management Conf. 7: 239-242.

Willard D.A., Cooper S.R., Gamez D., Jenshen J. 2004. Atlas of pollen and spores of the Florida everglades. Palynology 28: 175-227.

Xu F., Sun M. 2001. Comparative analysis of phylogenetic relationships of grain amaranths and their wild relatives (Amaranthus; Amaranthaceae) using internal transcribed spacer, amplified fragment length polymorphism, and doubleprimer fluorescent inter simple sequence repeat markers. Mol. Phylogen. Evol. 21: 372-387.

Zhigila D.A., Sawa F.B.J., Abdul S.D., Danailu G. 2014a. Diversity of pollen morphology in accessions of Sesamum indicum L. Int. J. Modern Bot. 4: 22-28.

Zhigila D.A., Yuguda U.A., Akawu J.J., Oladele F.A. 2014 b. Palynomorphs and floral bloom as taxonomic characteristics in some species of the genus Amaranthus L. (Amaranthaceae). Bayero J. Pure Appl. Sci. 7: 164-168. 